\title{
A Field Experiment with Drifting Hoop Nets to Collect the Small Fish Gathering around Drift Algae
}

\author{
Hideaki Nakata, ${ }^{* 1}$ Hiroji Takeuchi, ${ }^{* 2}$ and Toshiyuki Hirano*3 \\ (Received May 26, 1988)
}

\begin{abstract}
A field experiment with drifting hoop nets was carried out in the coastal water of the Kuroshio during 6-12 August 1977 in order to collect the small fish associated with drift algae. Two types of drifting hoop nets composed of 5 large $\left(0.83 \mathrm{~m}^{3}\right)$ and small $\left(0.22 \mathrm{~m}^{3}\right)$ hoop nets were released about 50 miles off Shikoku on 6 August and tracked; each type was retrieved twice during the tracking to catch the fish in the nets. The juvenile and young fish of 9 species ( 7 families) were collected including Arothron firmamentum (467 ind.), Abudefduf vaigiensis (71 ind.), Thamnaconus modestus (70 ind.) and Decapterus maruadsi ( 8 ind.). The greater part of the fish were collected with $7 \mathrm{~mm}$ mesh large nets. T. modestus and $D$. maruadsi were mostly collected at a depth of about $13 \mathrm{~m}$ in contrast to $A$. vaigiensis and $A$. firmamentum which were collected at the surface. Body lengths (ranging $80-108 \mathrm{~mm}$ in BL) of $T$. modestus were somewhat larger than previously reported. The appearance of young $A$. firmamentum suggests that they possibly migrated in and around the Kuroshio Current off Shikoku during the period of this experiment.
\end{abstract}

Various drifting objects on the sea surface play a major role as a habitat of larval and juvenile fish. Among them, drift algae are most popular and of great importance. ${ }^{1-7)}$ It has been reported that the small fish associated with drift algae would be given shelter which may be advantageous to their survival. ${ }^{7-9)}$

In order to clarify the ecological characteristics of small fishes which generally associate with drift algae, a great many efforts have been made to collect them in the sea using scoop-nets, small roundhauls, spoon nets or other ichthyoplankton nets. According to Senta, ${ }^{4)} 51$ families and 113 species of fishes are listed as fishes which have been collected around the drift algae. In addition, some experimental studies on the mechanism of the association of the fish were carried out using both various floating objects in the field $^{10,11}$ and water tank experiments in the laboratory.12-15) Further, it has become possible in recent years to quantitatively study the processes of aggregation of the small fish such as juveniles of yellowtail in relation to oceanic conditions. ${ }^{\text {is) }}$

In this paper, we describe a field experiment with drifting hoop nets to collect the small fish associated with drifting objects. The work was carried out in the coastal water adjacent to the Kuroshio Current on 6-12 August 1977 during the R.V. Hakuho-maru cruise KH-77-2, A peculiar point of this experiment is that the drifting object itself has a function of collecting the fish in addition to attracting them to the object. It also seems to be a special advantage that both information about water movement and aggregating fish can be obtained from the drifting condition of the net. Additional installation of relevant instruments in the drifting net system will enable more information of other oceanic conditions to be obtained while a net is drifting. The results described here are still primitive; nevertheless they have stimulated us to further efforts to apply this method to an ecological study of the fish gathering around the drift algae.

\section{Methods}

Characteristics of the hoop nets used for this experiment are summarized in Table 1. Large hoop nets (LO-L4) have the same size as those

*1 Ocean Research Institute University of Tokyo, Minamidai, Nakano, Tokyo 164, Japan (中田英昭: 果京大学海洋研究所).

*2 Tachikawa Girls' Highschool, Takamatsu, Tachikawa, Tokyo 190, Japan（竹内博治：立川女子高等 学校).

*z Faculty of Marine Science and Technology, Tokai University, Orido, Shimizu, Shizuoka 424, Japan (平野微行：東海大学海洋学部). 
Table 1. Characteristics of the hoop nets used for the present study

\begin{tabular}{llcccc}
\hline \hline Type & Net No. & $\begin{array}{c}\text { Volume } \\
\left(\mathrm{m}^{8}\right)\end{array}$ & $\begin{array}{c}\text { Mesh size } \\
(\mathrm{mm})\end{array}$ & Flapper & Seaweed \\
\hline FL & L0 & 0.83 & 20 & + & + \\
& L1-L3 & 0.83 & 7 & & + \\
FS & L4 & 0.83 & 7 & + & + \\
& S1-S4 & 0.22 & 15 & + & + \\
\hline
\end{tabular}

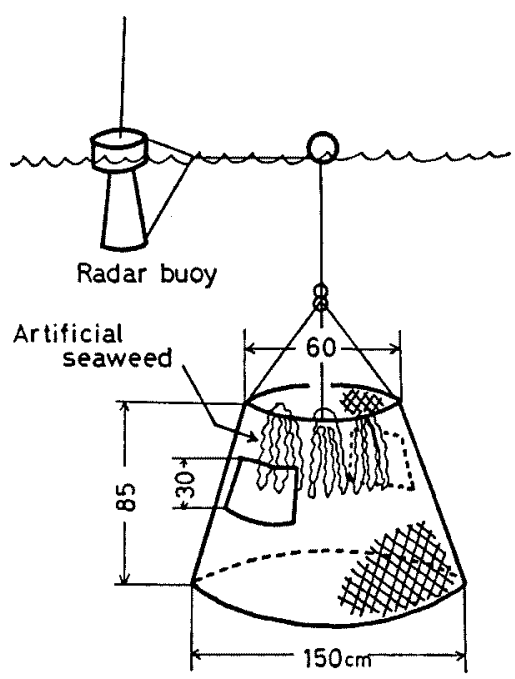

(a)

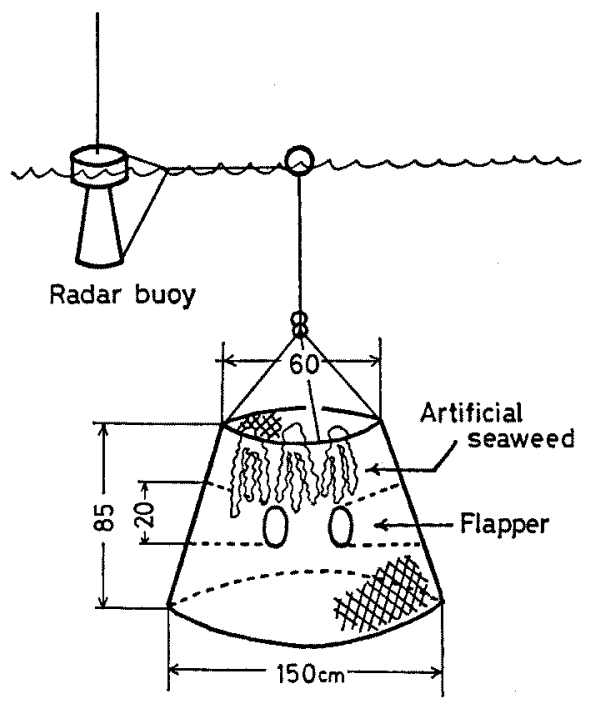

(b)

Fig. 1. Large hoop nets used for the present study.

(a): hoop net without flapper, (b): hoop net with flapper.

generally used as a fishing gear to catch crabs and shrimps, while small ones (S1-S4) have been used for various experimental work in the Tokai Fisheries Research Laboratory (Koyama, personal communication). The sizes of the large nets are shown in Fig. 1; nets L0 and L4 had a small flapper as shown in Fig. 1(b). The shape of the small net is the same as that of the large net with a flapper and its sizes are almost half that of the large net. In addition, several bundles (about $50 \mathrm{~cm}$ in length) of semitransparent artificial seaweed made of vinyl were attached to the upper part of each hoop net to enhance the attraction of the net upon the fish.

Two combinations of the above described large and small hoop nets were used for the experiment. These were the FL and FS types shown in Fig. 2. The position of the drifting hoop net was determined by the help of a radar transponder buoy connected to it. The nets were launched at 11:50 (FL type) and 12:08 (FS type) on 6 August 1977 at $\operatorname{Stn} . \mathrm{A}\left(31^{\circ} 54.7^{\prime} \mathrm{N}, 133^{\circ} 40.4^{\prime} \mathrm{E}\right)$. The FL type was first retrieved at 13:40 on 9 August at Stn. $\mathrm{B}\left(32^{\circ} 00.6^{\prime} \mathrm{N}, 134^{\circ} 05.6^{\prime} \mathrm{E}\right)$ and re-launched from that point after sampling fishes caught in the nets, and finally retrieved at 9:50 on 11 August at Stn. D $\left(31^{\circ} 33.6^{\prime} \mathrm{N}, 134^{\circ} 47.9^{\prime} \mathrm{E}\right)$. The FS type was retrieved first at 17:00 on 10 August at Stn. C $\left(31^{\circ} 34.5^{\prime} \mathrm{N}, 134^{\circ} 41.2^{\prime} \mathrm{E}\right)$ and finally at $10: 15$ on 12 August at Stn. E $\left(30^{\circ} 17.8^{\prime} \mathrm{N}, 136^{\circ} 17.0^{\prime} \mathrm{E}\right)$. The launch and retrieval points are shown in Fig. 3 , together with the horizontal distribution of water temperature at a depth of $200 \mathrm{~m}$ in August 1977. The collected fish samples were all preserved in $30 \%$ solution of buffered formalin, and provided for later sorting and determination of the stomach contents.

Seven other surface drifters with a current shade made of canvas instead of the hoop nets were launched from almost the same point as the drifting hoop nets on 6 August, and tracked together with the hoop nets.* The trajectories of

\footnotetext{
* T. Hirano and K. Hasunuma: Preprint Ann. Spring Mtg., Oceanogr. Soc. Japan, 70 (1978).
} 


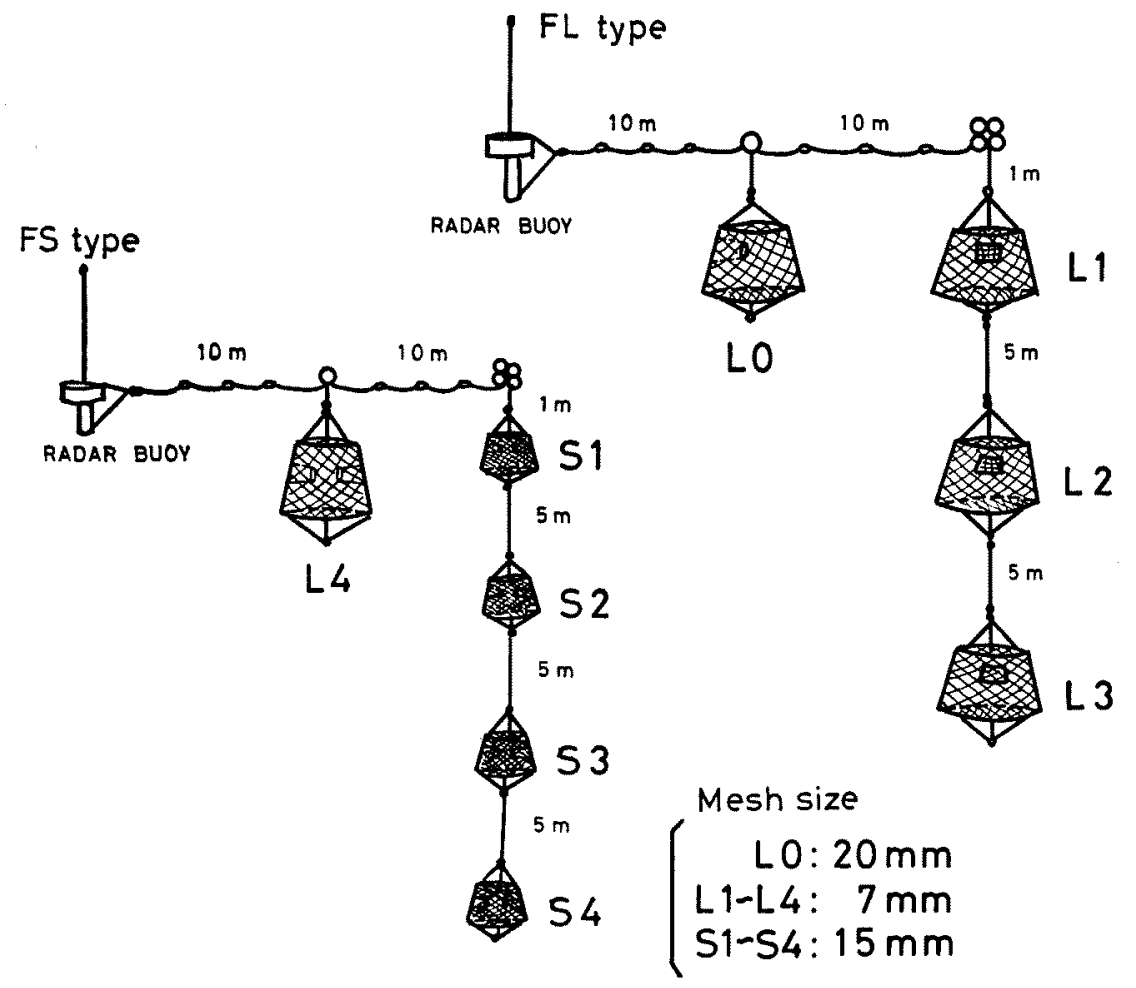

Fig. 2. Configuration of two types of the drifting hoop net (FL and FS types).

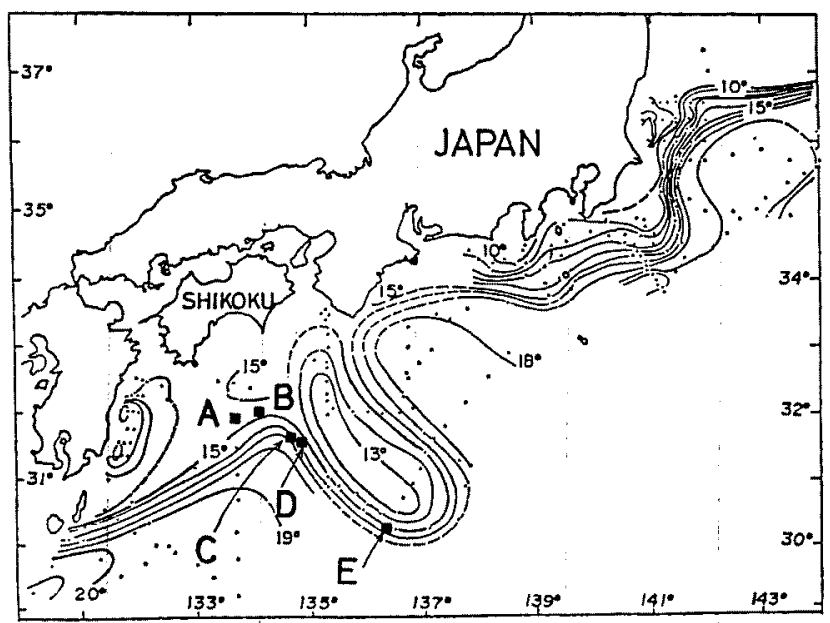

Fig. 3. Temperature distribution at a depth of $200 \mathrm{~m}$ during the KH-77-2 cruise. The launch (Stn. A) and retrieval points (Stns. B-E) of the drifting hoop nets are also indicated. The temperature data was based on the observations during the cruise and routine observations of the fisheries experimental stations around the Kuroshio and adjacent seas conducted in August 1977. 
these drifters are referred for information about current conditions in the experiment area. In addition, 1,000 surface drift-cards (in total) were released from the launch and retrieval points of the drifting hoop nets; however none of them were recovered.

\section{Results}

As inferred from temperature distribution in Fig. 3, drifting hoop nets were first launched in the coastal water of the Kuroshio Current off Shikoku. However, they were gradually entrained into the Kuroshio as time elapsed and moved towards the southeast along the meandering path of Kuroshio. Fig. 4 shows the trajectories of surface drifters with a current shade, which are almost similar to those of the drifting hoop nets as suggested by the location of their retrieval points indicated in the figure. The drift speeds of the drifters increased to 2-3 knots during the latter half of the tracking period, while they were comparatively slow (0.5-1 knots) within 3-4 days after the launch. It is also noted that the dispersion of the drifters in the direction perpendicular to the current is extremely small compared to that in the direction of the current, which suggested that the coastal water entrained into the Kuroshio may be elongated along the current due to the effect of current shear.
As shown in Table 2, fishes collected with the drifting hoop nets were composed of 9 species (7 families), most of which have previously been reported as species or families with a tendency to associate with drift algae.") It is obvious from the table that the greater part of the fish were collected with $7 \mathrm{~mm}$ mesh large nets (L1-L4), though the sampling with $L 1$ at the first retrieval was unsuccessful and hence the catch data was lost. The large net with the flapper (L4) caught the most fish; nevertheless the effect of the flapper still seems to be uncertain because the catch with L4 included a cluster of Arothron firmamentum which is regarded as a transient. ${ }^{\theta)}$ The total number of the fish except for $A$. firmamentum collected at the first retrievals (at Stns. B and C) was evidently larger than that at the second ones (at Stns. D and E). This may be due to the difference between drift areas of the nets. Before the first retrieval the nets mostly travelled in the coastal water, and after that they were gradually entrained into the offshore Kuroshio water (Fig. 4).

Table 3 shows the body sizes (TL and BL) and body weight of the fish collected with the hoop nets. Most of the fishes except for A. firmamentum were juveniles as expected from the previous reports. ${ }^{1-\vartheta)}$ However, the size of Thamnaconus modestus ( $80.0-108.0 \mathrm{~mm}$ in $\mathrm{BL}$ ) is somewhat larger than the size limits $\left(90 \mathrm{~mm}^{3}\right)$ and $70 \mathrm{~mm}^{4}$ ) in $\mathrm{TL}$ ), previously reported for this

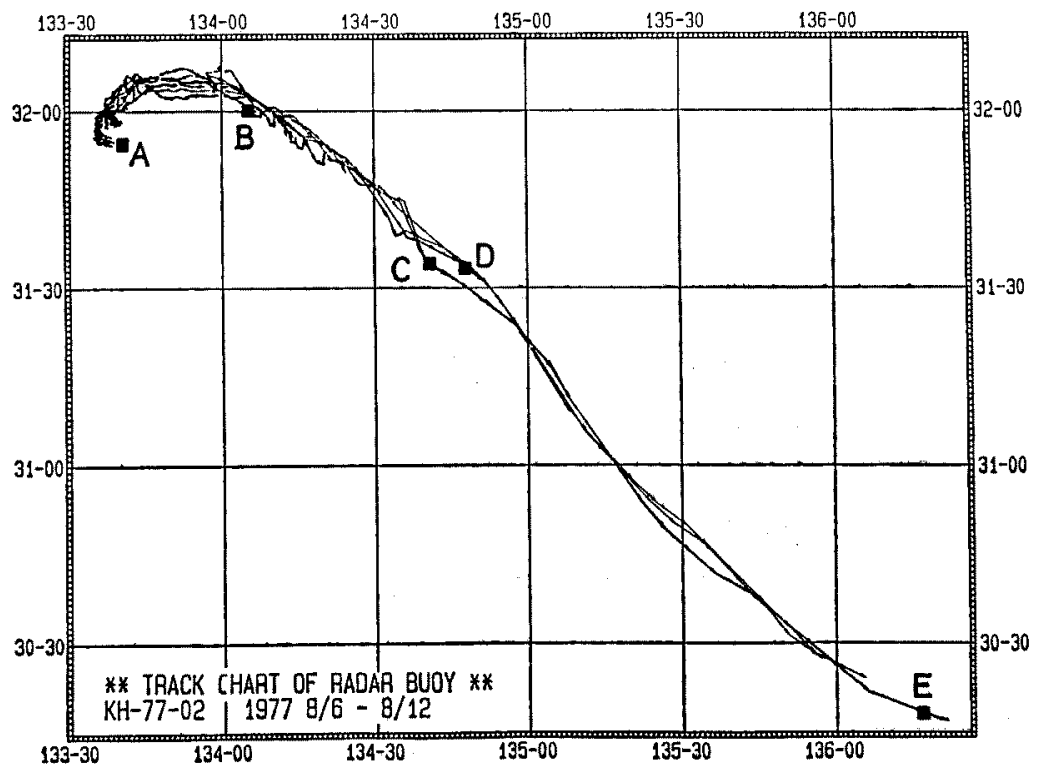

Fig. 4. Trajectories of the surface drifters launched and tracked together with the drifting hoop nets. The launch (Stn. A) and retrieval points (Stns. B-E) of the hoop nets are also indicated. 
Table 2. List of the fish collected with the drifting hoop nets

\begin{tabular}{|c|c|c|c|c|}
\hline Date (1977) & Retrieval point & Net No. & Species name & Number \\
\hline \multirow[t]{4}{*}{ Aug. 9} & $\mathbf{B}$ & LO & Rhyncopelates oxyrhynchus & 2 \\
\hline & & $\mathbf{L 3}$ & Thamnaconus modestus & 53 \\
\hline & & & Decapterus maruadsi & 6 \\
\hline & & & Psenes sp. & 1 \\
\hline \multirow[t]{7}{*}{ Aug. 10} & $\mathrm{C}$ & L4 & Arothron firmamentum & 467 \\
\hline & & & Abudefduf vaigiensis & 55 \\
\hline & & & Seriola dumerili & 1 \\
\hline & & & Siganus sp. & 1 \\
\hline & & & Psenes sp. & 1 \\
\hline & & S2 & Abudefduf vaigiensis & 1 \\
\hline & & S4 & Thamnaconus modestus & 1 \\
\hline \multirow[t]{5}{*}{ Aug. 11} & D & L1 & Abudefduf vaigiensis & 5 \\
\hline & & L2 & Seriola lalandi & 1 \\
\hline & & & Abudefduf vaigiensis & 1 \\
\hline & & L3 & Thamnaconus modestus & 15 \\
\hline & & & Decapterus maruadsi & 2 \\
\hline \multirow[t]{2}{*}{ Aug. 12} & $\mathbf{E}$ & L4 & Abudefduf vaigiensis & 9 \\
\hline & & & Thamnaconus modestus & 1 \\
\hline
\end{tabular}

Table 3. Body sizes and weight of the fish collected with the drifting hoop nets

\begin{tabular}{|c|c|c|c|c|c|c|c|c|c|c|c|c|c|}
\hline \multirow[t]{2}{*}{ Species name } & \multirow{2}{*}{$\begin{array}{l}\text { Total } \\
\text { ind. }\end{array}$} & \multicolumn{4}{|c|}{ Total length (mm) } & \multicolumn{4}{|c|}{ Body length (mm) } & \multicolumn{4}{|c|}{ Body weight (g) } \\
\hline & & $\max$ & mean & $\min$. & SE & $\max$ & mean & $\min$. & SE & $\max$. & mean & $\min$ & $\mathrm{SE}$ \\
\hline A. firmamentum & 467 & 121 & 112.5 & 102 & 0.56 & 100 & 92.4 & 85 & 0.47 & 26.2 & 20.0 & 16.0 & 3.25 \\
\hline A. vaigiensis & $70^{* 1}$ & 34 & 25.8 & 13 & 4.14 & 25 & 19.0 & 12 & 3.24 & 0.75 & 0.32 & 0.07 & 0.16 \\
\hline$T$. modestus & 70 & 118 & 106.7 & 100 & 5.31 & 108 & 89.0 & 80 & 4.12 & 18.7 & 13.3 & 10.5 & 2.24 \\
\hline D. maruadsi & 8 & 46 & 39.6 & 31 & 5.50 & 38 & 31.1 & 25 & 3.85 & 0.95 & 0.48 & 0.30 & 0.20 \\
\hline R. oxyrhynchus & 2 & 93 & 81.0 & 69 & - & 85 & 67.0 & 49 & - & 14.4 & 10.4 & 6.4 & - \\
\hline Psenes sp. & 2 & $\neq 2$ & - & 138 & 一 & 123 & 108.5 & 96 & - & 52.3 & 41.3 & 30.3 & - \\
\hline S. dumerili & 1 & - & (83) & - & - & - & $(67)$ & - & - & - & $(8.5)$ & - & - \\
\hline S. lalandi & 1 & - & (87) & - & - & - & (68) & - & - & - & $(8.4)$ & - & - \\
\hline Siganus sp. & 1 & - & (65) & - & - & - & $(50)$ & - & - & - & $(4.8)$ & - & - \\
\hline
\end{tabular}

-1 One large individual of A. vaigiensis (TL: $69 \mathrm{~mm}$, BL: $49 \mathrm{~mm}$, BW: 6.4 g), which was collected with the net L2 on 11 August, was omitted from this statistic.

*2 The measurement was disabled because the fish was damaged.

Table 4. The number of the fish collected with the $7 \mathrm{~mm}$ mesh large hoop nets by the depths where the nets were suspended

\begin{tabular}{lccc}
\hline \multicolumn{1}{c}{ Species } & \multicolumn{3}{c}{ Depth of the hoop net } \\
\cline { 2 - 4 } & $1 \mathrm{~m} \mathrm{(L1} \mathrm{and} \mathrm{L4)}$ & $7 \mathrm{~m}(\mathrm{L2})$ & $13 \mathrm{~m}(\mathrm{L3})$ \\
\hline A. firmamentum & 467 & 1 & \\
A. vaigiensis & 69 & & 68 \\
$T$. modestus & 1 & & 1 \\
D. maruadsi & 1 & 1 & \\
Psenes sp. & 1 & & \\
S. dumerili & & & \\
S. lalandi & 1 & & \\
Siganus sp. & & & \\
\hline
\end{tabular}


Table 5. Stomach contents of the fish collected with the drifting hoop nets. Values indicate the percentage of the appearance of each itemized food organism in the stomach of the fish collected in the present experiment. In the case of A. firmamentum, 50 individuals (out of 467 ind.) were provided for the analysis

\begin{tabular}{|c|c|c|c|c|c|c|c|c|c|c|}
\hline \multirow{2}{*}{ Species } & \multicolumn{10}{|c|}{ Food organisms } \\
\hline & A & B & C & $\mathrm{D}$ & $\mathbf{E}$ & $F$ & $G$ & $\mathbf{H}$ & I & $\mathbf{J}$ \\
\hline A. firmamentum & & & & & & & & & & $100.0 \%$ \\
\hline A. vaigiensis & $70.3 \%$ & & & & $8.1 \%$ & $43.2 \%$ & $2.7 \%$ & $10.8 \%$ & $2.7 \%$ & $8.1 \%$ \\
\hline$T$. modestus & 75.6 & $13.7 \%$ & $9.8 \%$ & $41.5 \%$ & 2.4 & & 4.9 & & 7.3 & 9.8 \\
\hline D. maruadsi & 50.0 & & & & & & & & & 12.5 \\
\hline Psenes sp. & & & & & & & & & & 100.0 \\
\hline R. oxyrhynchus & 100.0 & 100.0 & & & & & & & & \\
\hline S. aumerili & & & & & & & & & 100.0 & \\
\hline S. lalandi & & & & & & & & & 100.0 & \\
\hline Siganus sp. & 100.0 & & & & 100.0 & & & & & \\
\hline
\end{tabular}

species during a period of association with drift algae, while the sizes of Abudefduf vaigiensis (12.0$25.0 \mathrm{~mm}$ in BL) and Seriola dumerili $(67.0 \mathrm{~mm}$ in BL) are both consistent with those previously reported. ${ }^{3,4)}$ A cluster of $A$. firmamentum, which was collected with one hoop net (L4), has similar sizes ranging between $102.0-121.0 \mathrm{~mm}$ in TL. According to Tabeta (personal communication), such sizes correspond to the young stage of this species.

On the other hand, Table 4 shows the number of the fish which were collected with the $7 \mathrm{~mm}$ mesh large nets (L1-L4) by depths where the nets were suspended; L1 and L4 were drifted in the surface water (about $1 \mathrm{~m}$ deep), while $\mathrm{L} 2$ and L3 were suspended at depths of about $7 \mathrm{~m}$ and $13 \mathrm{~m}$, respectively (Fig. 2). One can see that juveniles of $A$. vaigiensis and young of $A$. firmamentum were mostly collected in the surface water, while those of $T$. modestus and Decapterus maruadsi were generally in the layer about $13 \mathrm{~m}$ deep.

Results of the stomach contents determination are summarized in Table 5. Although stomach contents of all individuals of $A$. firmamentum provided for the determination and Psenes sp. were empty of food, most of the others had largely ingested copepods, except for $S$. dumerili and $S$. lalandi which only fed on fish larvae. The stomach contents of $T$. modestus were very varied and a relatively high percentage $(41.5 \%)$ of the juveniles of $T$. modestus fed on amphipods. It was also noted that polychaete larvae fed $43.2 \%$ of $A$. vaigiensis. Fish eggs were found in the stomach contents of $A$. vaigiensis, though the percentage was small. These results suggest that zooplankton in the water marked with the drifting hoop net would mainly feed the fishes collected with the hoop nets. Ida et al. ${ }^{17)}$ also pointed out that most small fishes associating with drift algae in Sagami Bay largely fed on copepods.

It should be noted that 4 dolphins, Coryphaena hippurus, accompanying the hoop nets were caught by angling at Stn. D. One dolphin and one triggerfish, Balistes conspicillum, were also caught at Stn. E. These facts may support the predatory behaviour of such fish towards the small fish associating with drift algae. ${ }^{18)}$

\section{Discussion}

It has been recently reported that small fishes were comparatively abundant around algae drifting even in open water and had a tendency to be quickly attracted to clumps of algae which were experimentally left to drift." According to Yoshida, ${ }^{19)}$ drift algae in the sea around Japan are mainly distributed in the coastal water and rarely found in the offshore Kuroshio Current or Tsushima Warm Current. In addition, the abundance of drift algae reaches a peak in May or June $^{18)}$ and decreases after August. ${ }^{8,20)}$ Therefore, there would be little drift algae in the area of the present experiment with drifting hoop nets. This may have had a large contribution upon gathering the small fish around the hoop net.

The experiment showed that the $7 \mathrm{~mm}$ mesh large hoop nets (L1-L4) were the most effective means of gathering and collecting small fishes (Table 2). On the basis of a field experiment with various floating objects moored off the coast of Costa Rica, Hunter and Mitchell ${ }^{11}$ suggested that an object with a tent-like three-dimensional struc- 
ture is more effective in attracting fish than a sheet-like structure, and that larger and shadier objects are more attractive still. In the present experiment, all hoop nets had three-dimensional structures as shown in Figs. 1 and 2 . In addition to this, nets L1-L4 have a size advantage compared to the small nets (S1-S4) and more shade due to a smaller mesh size compared to LO $(20 \mathrm{~mm}$ mesh large net). These advantages of the $7 \mathrm{~mm}$ mesh large nets resulted in a large catch of the small fishes generally associated with drift algae.

Although the attraction of small fish to the drifting hoop net was expected to some extent, it should be emphasized that the hoop net could collect the fish gathering around the net. This indicates the possibility of an experiment on the ecology of the small fish associated with drift algae using such a drifting hoop net. This promising method seems to be particularly useful in collecting small fishes swimming in relatively offshore water where drift algae are scanty. Further experiments are necessary on the effects of the size, shape and structure of the hoop net, including the effects of using the flapper, artificial seaweed, etc., on the collection of fish.

On the other hand, the fishes collected with the drifting hoop net were mostly juveniles (Table 3 ), most of the species have been reported as residents in and around drift algae. ${ }^{\theta)}$ Judging from the stomach contents (Table 5) of the fishes, they mainly fed on the zooplankton such as copepods in the water around the hoop net. The small fish swirmming without drift algae in the offshore water seem to have an impulse to accompany the hoop net as suggested by Senta. The reduction in the number of the fish collected in the Kuroshio water (Table 2) may be due to small amount of the fish which were able to encounter the drifting hoop net.

It is noticeable that the body length (ranging $80-108 \mathrm{~mm}$ in $\mathrm{BL}$ ) of $T$. modestus collected with the hoop nets is somewhat larger than the previously reported size of this species during the period of association with drift algae. ${ }^{3,4}$ Most of species which are known to associate with drift algae in their juvenile periods have to leave the drift algae at a certain critical size and shift to another habitat. ${ }^{4,0)}$ However, this critical size, which also means the duration of the association with the drift algae, is considered indefinite and possibly varies according to the environmental conditions of the fish.4,5) In the offshore water, there seem to be fewer chances to find another habitat away from the drift algae compared to the situation in the coastal water. This may result in the longer period of association inferred from the appearance of the larger sized $T$. modestus juveniles mentioned above.

In addition, the fact that the juveniles of $T$. modestus were mostly collected with the hoop nets suspended at a depth of about $13 \mathrm{~m}$ (Table 4 ) is interesting. The juveniles of $D$. maruadsi ranging $25-38 \mathrm{~mm}$ in $\mathrm{BL}$ were also collected with the same net as $T$. modestus, while $A$. vaigiensis and $A$. firmamentum were mostly collected in the surface water. It is suggested that the main habitat of $T$. modestus juveniles would become deeper after reaching a certain size; a further investigation of the depth inhabited by $T$. modestus is required.

A. firmamentum is known as a fish which migrates from the south of Taiwan to the sea around Japan and is often driven to the shore of the Japan Sea in winter in the same way as Diodon holacanthus.* Although the ecological information on this species is still limited, it has been reported that a large number of young of this species appeared in the sea around western Japan between September 1977 and February 1978*. Since there has been no record of the appearance of this species around Nansei Islands which are located in the path of the Kuroshio Current passing by the south of Kyushu, it is assumed that most of the young of A. firmamentum are transported on the continental shelf lying north of the Kuroshio.* However, the appearance of a cluster of the young fish in the coastal water of the Kuroshio off Shikoku as described in this study suggests that the young could be transported in and around the Kuroshio Current passing through the Nansei Islands in summer 1977. Judging from the stomach content of $A$. firmamentum, which proved to be empty, and negative results from the drift-cards released from the points along the drift route of the hoop nets, the migrating young probably perish.

There has been no record of sampling of the young $A$. firmamentum associating with drift algae. Although the behavioural response of this species to drifting objects is also unknown, it seems to be reasonable to regard this species as a transient like other puffer fishes. ${ }^{\theta}$ ) The drifting hoop net may be a promising sampling method to collect fishes which have the same migrating characteristics as $A$. firmamentum.

* O. Tabeta and A. Kataoka: Preprint Ann. Fall Mtg., Nippon Suisan Gakkai, 59 (1978). 


\section{Acknowledgements}

We wish to express our sincere thanks to $\mathrm{Mr}$. T. Koyama, who kindly lent us the small hoop nets and provided helpful information on fish sampling when he was at the Tokai Regional Fisheries Research Laboratory, and to Dr. $O$. Tabeta, Shimonoseki University of Fisheries, who provided valuable information on the ecological characteristics of $A$. firmamentum. We also thank the captain and crews of R. V. Hakuhomaru for their assistance at sea, and Taito Seiko Co., Ltd. for their help with designing the large hoop nets. Thanks are due to Mrs. K. Matsuo for her help with preparation of the hoop nets, to Mrs. K. Nakata for her help with illustrations and to Mr. S. Clark for correcting the English. This study was supported by a scientific research grant from the Ministry of Enducation, Science and Culture, Japan.

\section{References}

1) K. Uchida and Y. Shojima: Nippon Suisan Gakkaishi, 24, 411-415 (1958).

2) Y. Shojima and K. Ueki: Nippon Suisan Gakkaishi, 30, 248-254 (1964).

3) Y. Hirosaki: Miscel. Rep. Res. Inst. Natur. Resources, 61, 77-84 (1963).

4) T. Senta: in "Importance of Drifting Seaweeds in the Ecology of Fishes", Study Series 13, Japan
Fisheries Resource Conservation Association, Tokyo, 1965, pp. 1-55.

5) H. Ida, Y. Hiyama, and T. Kusaka: Nippon Suisan Gakkaishi, 33, 923-929 (1967).

6) H. Ida: Mar. Sci. Monthly, 18, 693-698 (1986).

7) M. J. Kingsford and J. H. Choat: Limnol. Oceanogr., 30, 618-630 (1985).

8) T. Asami, T. Koto, and F. Hanaoka: Bull. Japan. Soc. Fish. Oceanogr., 28, 90-102 (1975).

9) F. Hanaoka: Rep. Fish. Res. Invest. Japan. Gov., 22, 99-107 (1981).

10) T. Senta: Nippon Suisan Gakkaishi, 32, 639-642 (1966).

11) J. R. Hunter and C. T. Mitchell: J. Cons, int. Explor. Mer, 31, 427-434 (1968).

12) S. Kojima: Nippon Suisan Gakkaishi, 22, 730735 (1957).

13) Y. Hirosaki: J. Fac. Sci. Hokkaido Univ. Ser. VI (Zool.), 14, 320-326 (1960).

14) T. Senta: Nippon Suisan Gakkaishi, 32, 643646 (1966).

15) T. Senta: Nippon Suisan Gakkaishi, 32, 693-696 (1966).

16) F. Hanaoka: Mar. Sci. Monthly, 18, 719-724 (1986).

17) H. Ida, Y. Hiyama, and T. Kusaka: Nippon Suisan Gakkaishi, 33, 930-936 (1967).

18) S. Kojima: Nippon Suisan Gakkaishi, 29, 507513 (1963).

19) T. Yoshida: Bull. Tohoku Reg. Fish. Res. Lab., 23, 141-186 (1963).

20) M. Ono: Nippon Suisan Gakkaishi, 50, 16531656 (1984). 